\title{
ANALISIS PENILAIAN KINERJA DOSEN MENGGUNAKAN METODE BALANCE SCORECARD (STUDI KASUS STT SANGKAKALA)
}

\author{
Ibar Adi Permana \\ ibariap12@gmail.com
}

Teknik Elektronika, Politeknik Tri Mitra Karya Mandiri, Karawang, Indonesia

\section{Info Artikel}

Sejarah Artikel:

Diterima : 1 Juli 2020

Disetujui : 25 Juli 2020

Dipublikasikan : 15

Agustus 2020

Keywords:

Balance Scorecard ;

kinerja; dosen

\begin{abstract}
Abstrak
Tujuan dari penelitian ini adalah untuk melakukan penilaian kinerja dosen berdasarkan beban kerja dosen pada institusi STT Sangkakala. Selama ini kegiatan evaluasi kinerja dosen hanya dalam konteks Pendidikan, sehingga belum mencakup keseluruhan pelaksanaan tri dharma perguruan tinggi yang dilaksanakan oleh dosen. Metode yang digunakan dalam penelitian ini adalah metode kualitatif dengan pendekatan balance scorecard. Penilaian kinerja dosen memiliki 3 strategic objectives yaitu perseptif finansial, perspektif pelanggan, dan perspektif proses bisnis internal. Sedangkan pendukung pengembangan perangkat lunak dalam penilaian kinerja dosen yang merupakan sumber data bagi penilaian kinerja dosen pada institusi STT Sangkakala terdapat beberapa subsitem-subsistem yaitu: Subsistem EKEU, subsistem EDOM, subsistem EDOS, subsistem EPRODI, subsistem EP3M, dan subsistem ADAK.
\end{abstract}

ANALYSIS OF LECTURER PERFORMANCE ASSESSMENT USING BALANCE SCORECARD METHOD (CASE STUDY IN STT SANGKAKALA)

\begin{abstract}
The purpose of this study is to assess the performance of lecturers based on the workload of lecturers at the Sangkakala STT institution. During this time the performance evaluation of lecturers is only in the context of Education, so it does not cover the whole implementation of the tri dharma of tertiary institutions carried out by lecturers. The method used in this study is a qualitative method with a balance scorecard approach. Lecturer performance appraisal has 3 strategic objectives namely financial perceptive, customer perspective, and internal business process perspective. While supporting software development in evaluating lecturer performance is a source of data for assessing lecturer performance at the STT Sangkakala institution there are several subsystems, namely: EKEU subsystem, EDOM subsystem, EDOS subsystem, EPRODI subsystem, EPRODI subsystem, EP3M subsystem, and ADAK subsystem
\end{abstract}




\section{PENDAHULUAN}

Evaluasi kinerja dosen sangat dibutuhkan oleh perguruan tinggi yang bertujuan untuk meningkatkan kualitas internal secara berkelanjutan. Penilaian kinerja dosen ini mencakup pelaksanaan kegiatan tri dharma perguruan tinggi yaitu pendidikan, penelitian, dan pengabdian kepada masyarakat yang dilakukan oleh masing-masing dosen. Monitoring evaluasi dosen yang selama ini dilakukan adalah berupa rekapitulasi yang bersumber dari data-data kuesioner mahasiswa yang membahas terkait proses belajar mengajar saja. oleh sebab itu, permasalahan tersebut mempunyai dampak pada beberapa hal yaitu (1) proses pengolahan data yang lama karena berupa data kuesioner yang diisi mahasiswa, (2) hasil evaluasi dosen hanya mencakup pendidikan saja belum mengkover penelitian dan pengabdian masyarakat, (3) hasil evaluasi kinerja belum sesuai dengan pedoman institusi, (4) institusi sulit untuk menentukan kebijakankebijakan terkait dengan peningkatan kualitas dosen, (5) salah satu penilaian akreditasi adalah riwayat pelaksanaan kegiatan tridharma perguruan tinggi oleh dosen yang akan menjadi hambatan bagi kampus.

Beban kerja dosen merupakan sejumlah pekerjaan yang ditugaskan oleh pimpinan perguruan tinggi kepada dosen untuk melaksanakan tugas tridharma perguruan tinggi dan atau tugas tambahan dalam masa tertentu yang diukur dalam satuan kredit semester/sks meliputi (1) bidang pendidikan, (2) bidang penelitian dan pengembangan ilmu, (3) bidang pengabdian kepada masyarakat, (4) penunjang tridharma perguruan tinggi. Beban kerja dosen sendiri secara ideal dalam melaksanakan tugas tridharma perguruan tinggi paling sedikit 12 SKS dan paling banyak 16 SKS pada tiap semester sesuai kualifikasi akademiknya. Dengan demikian kinerja tugas dosen adalah capaian hasil seorang dosen dalam melaksanakan sejumlah tugas tridharma yang menjadi kewajiban dan tanggungjawabnya selama satu semester.

Monitoring dan evaluasi kinerja dosen selama ini hanya berupa data-data yang bersumber dari kuesioner yang diisi oleh mahasiswa berkaitan proses belajar mengajar sehingga tidak mengcover kegiatan dosen di bidang penelitian dan pengabdian kepada masyarakat. Tentunya Sekolah Tinggi Teologi Sangkakala (STT Sangkakala) mempunyai komitmen untuk meningkatkan mutu/kualitas internal secara berkelanjutan dan menjadikan akreditasi sebagai strategi institusi untuk dapat bersaing dengan perguruan tinggi lain. Memperoleh dan mempertahankan status akreditasi tentu memerlukan komitmen dari yayasan, manajemen, dosen dan karyawan juga mahasiswa. Komitmen yang ingin ditingkatkan diantaranya adalah peningkatan kualitas dosen untuk menjaga kualitas dosen ini, institusi secara rutin melakukan monitoring dan evaluasi kinerja dosen sehingga setiap semester bahkan setiap bulan dapat dievaluasi untuk meningkatkan kinerja beban kerja dosen di bidang tri dharma perguruan tinggi.

Dari kondisi tersebut maka diperlukan penilaian kinerja secara komprehensif yang mencakup beban kerja dosen, reward and punishment, keuangan maupun non-keuangan dalam sebuah struktur perguruan tinggi. Penulis menawarkan system penilaian kinerja dosen menggunakan metode balanced scorecard. Keunggulan metode balanced scorecard ini ada pada Key Performance Indicator (KPI) sebagai metrik terkecil yang dimunculkan atas terjemahan strategi organisasi perguruan tinggi tersebut. KPI merupakan indikator/ukuran yang ingin dicapai untuk mengukur capaian kinerja terhadap sasaran strategi organisasi yang telah ditentukan. Penerapan balanced scorecard dalam analisis kinerja dosen di STT Sangkakala yang kemudian dirumuskan dalam berbagai inisiatif strategis yang dapat dilaksanakan institusi sehingga kinerja dosen dapat tercapai secara komprehensif, koheren, terukur dan seimbang. 


\section{TELAAH PUSTAKA \\ TEORI DASAR}

1.1.Kinerja

a. Pengertian penilaian kinerja

Ambar Tegus Sulistyani dan Rosidah (2009) mengungkapkan bahwa pada prinsipnya penilaian kinerja merupakan cara pengukuran kontribusi-kontribusi dari individu dalam instansi yang dilakukan terhadap organisasi. Nilai penting dari penilaian kinerja adalah menyangkut pada penentuan tingkat kontribusi individu atau kinerja yang di ekspresikan dalam menyelesaikan tugas-tugas yang menjadi tanggungjawabnya.

b. Tujuan penilaian kinerja

Tujuan penilaian kinerja adalah sebagai berikut:

1) Mengetahui tujuan dan sasaran manajemen dan pegawai

2) Memotivasi pegawai untuk memperbaiki kinerjanya.

3) Mendistribusikan reward dari organisasi/instansi yang berupa penambahan gaji/bonusi dan promosi yang adil

4) Mengandalkan manajemen penelitian personalia.

c. Manfaat penilaian kinerja

Penilaian kinerja berkontribusi bagi perencanaan kebijakan-kebijakan organisasi. Dalam hal ini menyangkut aspek individual dan aspek organisasional. Adapun secara terperinci manfaat penilaian kinerja bagi organisasi adalah sebagai berikut 1) penyesuaian kompensasi, 2) perbaikan kinerja, 3) kegiatan pelatihan dan pengembangan pegawai, 4) pengambilan keputusan dalam penempatan promosi, mutasi, pemecatan, pemberhentian dan perencanaan tenaga kerja, 5) kepentingan penelitian pegawai, dan 6) diagnosis terhadap kesalahan desain pegawai. Dalam kasus pada perguruan tinggi tentu penilaian kinerja dosen akan sangat berguna bagi penyusunan laporan evaluasi diri dan laporan kinerja baik institusi maupun program studi ketika perguruan tinggi akan menghadapi akreditasi baik internal maupun eksternal (BAN-PT).

\subsection{Balanced scorecard}

Balanced scorecard merupakan bagian dari sistim manajemen, pengukuran, dan pengendalian yang secara cepat, tepat, dan komprehensif sehingga dapat menjadi referensi bagi manajer untuk mengetahui performa bisnis. Pengukuran kinerja ini melihat unit bisnis dari empat perspektif yaitu perspektif keuangan, pelanggan, proses bisnis dalam perusahaan serta proses pembelajaran dan pertumbuhan. Melalui sebab akibat (cause and effect) perspektif keuangan menjadi perspektif utama yang dijelaskan oleh tolak ukur operasional pada tiga perspektif lainnya sebagai driver (lead indicator). (Sony Yuwono, dkk, 2006)

Balanced scorecard mengalami perkembangan dan penyempurnaan secara signifikan. Bahkan saat ini, balanced scorecard sudah berkembang dan mengalami evolusi dari hanya sekedar cara untuk melakukan evaluasi kinerja. Metode ini kini dapat disempurnakan dalam sistim manajemen dalam membangun pembelajaran organisasi. Pada beberapa penelitian, balanced scorecard dikembangkan sebagai alat untuk merumuskan strategi dan melakukan perubahan, bahkan semakin popular karena telah diintegrasikan dengan berbagai metode strategi bisnis yang terbukti dapat meningkatkan kinerja perusahaan secara signifikan. (Freddy Rangkuti, 2019) 


\section{ANALISIS PENILAIAN KINERJA DOSEN MENGGUNAKAN METODE BALANCED SCORECARD}

Pendidikan tinggi merupakan subsistem pendidikan nasional yang mencakup program diploma, sarjana, magister, spesialis dan doktor yang di selenggarakan oleh negara maupun swasta. Perguruan tinggi di Indonesia mempunyai kewajiban untuk menyelenggarakan tri dharma yakni pendidikan, penelitian dan pengabdian kepada masyarakat. Salah satu unsur dalam penyelenggaraan pendidikan tinggi adalah dosen. Dosen disini merupakan tenaga akademik yang bertugas merencanakan dan melaksanakan proses pembelajaran, menilai hasil pembelajaran, melakukan pembimbingan dan pelatihan, serta melakukan penelitian juga pengabdian kepada masyarakat. Beberapa penelitian, artikel, dan jurnal yang membahas tentang masalah penilaian kinerja diantaranya adalah:

Muhammad Fauzan (2012), menulis tentang peningkatan kinerja berbasis modal sosial dan dukungan organisasional di PTS Kota Semarang. Hasil penelitian menunjukkan bahwa (1) dimensi struktural modal sosial berpengaruh positif dan signifikan terhadap kinerja tugas dosen, (2) dimensi relasional modal sosial berpengaruh negatif terhadap kinerja tugas dosen, (3) gaya kepemimpinan transformasional tidak memoderasi hubungan dimensi struktural modal sosial dan kinerja tugas dosen, (4) gaya kepemimpinan transformasional memoderasi hubungan dimensi relasional modal sosial dan kinerja tugas dosen, (5) Tipe budaya klan tidak memoderasi hubungan dimensi struktural modal sosial dan kinerja tugas dosen, (6) Tipe budaya klan tidak memoderasi hubungan dimensi struktural modal sosial dan kinerja tugas dosen.

Hamzah, dkk (2010) membahas tentang sistem pendukung keputusan penilaian kinerja dosen dengan metode balanced scorecard, penelitian tersebut menggunakan studi kasus di Universitas Respati Yogyakarta.

Anung Pramudyo (2010) melakukan penelitian analisis faktor-faktor yang mempengaruhi kinerja dosen negeri pada kopertis wilayah V Yogyakarta. Dalam penelitian tersebut hasil yang didukung motivasi, kompetensi, dan keadilan kepemimpinan memiliki prediksi yang kuat untuk kinerja kuliah, tetapi lingkungan kerja tidak berpengaruh terhadap kinerja kuliah di Kopertis V Yogyakarta.

Haryono Setiadi (2008) meneliti terkait dengan pengembangan sistim informasi kenaikan jabatan fungsional akademik di Universitas Sebelas Maret. Dalam penelitian tersebut dibahas terkait dengan model proses bisnis kenaikan jabatan akademik yang kemudian dilakukan monitoring dan evaluasi angka kredit dosen.

\section{METODE}

Pada penelitian ini metodologi yang digunakan adalah pendekatan kualitatif dengan penekanan pada kajian secara rinci dan mendalam, mengupayakan pengambilan data, pencarian dan penemuan makna berarti, menekankan lebih pada proses dari pada hasil dan menggunakan logika berpikir secara induktif, alasannya adalah pendekatan tersebut dapat digunakan untuk memahami gejala secara menyeluruh, mendalam, dan apa adanya serta sesuai dengan pemikiran orang-orang yang ada didalamnya (miles dan hubberman, dan Bogdan \& Biklen). Berikut adalah ciri khas penelitian kualitatif a) peneliti adalah instrument utama penelitian, b) data penelitian pada umumnya berupa kata-kata gambar, c) penelitian lebih berorientesi pada proses dari pada hasil, d) analisis data lebih ditekankan pada analisis induktif, e) pencarian makna merupakan hal yang sangat penting (Bogdan dan Sari, Moleong, Sugiyono, dan Moehadjir). Penelitian studi kasus mengemukakan bahwa a) strategi penelitian yang cocok apabila pertanyaan pokok penelitian berkenaan dengan "bagaimana" dan "mengapa". Dan b) penelitiannya berfokus pada 
fenomena kontemporer dalam konteks kehidupan nyata, studi kasus ini sering digunakan untuk penelitian studi-studi organisasi dan manajemen. (Robert K Yin, 2004) dalam penelitian ini penggunaan metode-metode untuk mengeksplorasi dan memaknai makna baru yang oleh sejumlah individu atau sekelompok orang dianggap berasal dari masalah sosial. Proses penelitian kualitatif ini menggunakan desain penelitian studi kasus dalam arti penelitian difokuskan pada satu fenomena saja yang dipilih dan ingin dipahami secara mendalam, satu fenomena tersebut dapat berupa seorang pimpinan pendidikan tinggi, suatu program, suatu proses, satu penerapan kebijakan atau satu konsep sebagaimana di ungkapkan oleh Cresswell bahwa studi kasus merupakan strategi penelitian dimana didalamnya peneliti menyelidiki secara cermat suatu program, peristiwa, aktivitas, proses, atau sekelompok individu.

\section{ANALISIS DATA}

Pada pendekatan studi kasus dalam penelitian kualitatif adalah suatu cara khusus untuk pengumpulan data, pengorganisasian data, dan analisis data. Hal ini ditujukan agar pengumpulan informasi secara menyeluruh bersifat komprehensif, sistematis dan mendalam pada tiap-tiap kasus yang menarik. Pada penelitian ini analisis data berpedoman pada model interaktif. Maksudnya adalah analisis yang dilakukan secara interaktif dan berlangsung terus menerus. Model interaktif ini dapat menggambarkan suatu kerangka yang merangkum tiga rangkaian tahap analisis, Miles dan Hubberman (1994) menjelaskan bahwa aktivitas analisis data terdiri atas tiga tahap, yaitu: mereduksi data temuan (data reduction), penyajian data dengan analisisnya (data display) dan penarikan kesimpulan (conclusion drawing/verification) yang akurat tentang penggunaan metode balanced scorecard di STT Sangkakala. Reduksi data merupakan proses pemilihan, pemusatan perhatian abstraksi, dan pentransformasian data kasar yang muncul dari catatan tertulis di lapangan. Proses ini berlangsung selama penelitian dilakukan, dari tahap awal hingga akhir penelitian.

Pada tahap awal, analisis kerangka konseptual, permasalahan, pendekatan pengumpulan data yang diperoleh dengan membuat ringkasan, kode, mencari tema-tema. Dalam hal reduksi data ini, peneliti fokus pada hal-hal yang penting mengenai visi, misi, strategi, tujuan-tujuan strategi pada penggunaan metode balanced scorecard di STT Sangkakala. Data tersebut selanjutnya disederhanakan dengan mengklasifikasi data dasar tema yang terbagi pada beberapa perspektif balanced scorecard yaitu beban kerja dosen, upah/gaji, bonus, proses bisnis, aturan kepegawaian, dan learning \& growth. Penyajian data merupakan sekumpulan informasi yang tersusun dan memungkinkan untuk menarik kesimpulan serta pengambilan tindakan. Bentuk penyajiannya berupa teks naratif, matriks, grafik, dan bagan. Tujuannya untuk memudahkan membaca dan menarik kesimpulan. Dalam tahap ini peneliti dapat melakukan display (penyajian) antar bagian-bagian dalam konteks yang utuh, data tersebut diklasifikasikan berdasarkan tema-tema ini. Dalam tahap ini peneliti menyajikan data dalam bentuk bagan dan tabel mengenai visi, misi, tujuan, strategi, tujuan-tujuan strategis dan ukuran dari keempat prespektif balanced scorecard tersebut dalam ukuran strategis dari keempat perspektif balanced scorecard dan target yang ingin dicapai pada penilaian kinerja dosen di STT Sangkakala. Penarikan kesimpulan/verifikasi merupakan penarikan kesimpulan dari data yang telah dianalisis. Verifikasi tersebut merupakan uji kebenaran terhadap makna yang muncul dari data yang telah didisplaykan. Peneliti fokus pada abstraksi data yang tertuang dalam bagan visi, misi, strategi, ukuran-ukuran kinerja yang digunakan untuk mengukur pencapaian tujuan strategis dari keempat perspektif serta target yang ingin dicapai oleh STT Sangkakala. 


\section{HASIL DAN PEMBAHASAN}

Pada hasil dan pembahasan ini, akan dipaparkan keterkaitan visi, misi dan tujuan hingga pada aspek pengelolaan dosen dan penilaian kinerja dosen sebagai salah satu unsur penunjang dalam budaya mutu perguruan tinggi. Hal ini sangat penting mengingat dosen sebagai ujung tombak akademik sebuah perguruan tinggi yang dapat menggerakan roda kinerja produksi. Penerapan metode balanced scorecard lebih familiar dalam dunia perusahaan, namun dewasa ini metode balanced scorecard mulai banyak diterapkan dalam organisasi non-profit seperti perguruan tinggi. Metode ini sangat efektif untuk mengukur kinerja pegawai yang tentu didasari pada target dan capaian-capaian tertentu yang sudah ditetapkan oleh organisasi tersebut.

Secara profil STT Sangkakala sendiri mempunyai 3 program studi, yaitu 1) S1 Pendidikan Agama Kristen, 2) S1 Teologi, 3) S2 Teologi. Dosen tetap STT Sangkakal sebanyak 23. Dengan kualifikasi Pendidikan S3 sebanyak 8 orang dan S2 sebanyak 15 orang.

1. Penjabaran visi, Misi, dan Tujuan Strategik dalam peningkatan kinerja dosen

Penjabaran terhadap visi, misis dan tujuan strategik penulis tampilkan dalam bentuk tabulasi, seperti pada tabel 1. Tujuan-tujuan strategic masing-masing perspektif memiliki hubungan keterkaitan satu dengan yang lainnya. Adapun hubungan keterkaitan untuk tiap tujuan strategic dapat dilihat pada gambar 1 dibawah ini.

Tabel 1 Penjabaran Visi, Misi dan Tujuan Strategik

\section{Visi}

Menjadi Sekolah Tinggi Teologi yang menghasilkan hamba Tuhan yang berhasil

Misi

1. Menyelenggarakan pendidikan teologi Kristen yang Alkitabiah

2. Menyelenggarakan penelitian guna pengembangan teologi yang relevan

3. Menyelenggarakan pengabdian kepada gereja dan masyarakat

\begin{tabular}{|c|l|l|}
\hline No & \multicolumn{1}{|c|}{ Perspektif } & \multicolumn{1}{|c|}{ Tujuan-Tujuan Strategik } \\
\hline A & Finansial & $\begin{array}{l}\text { Kepuasan Mahasiswa } \\
\text { Kepuasan Dosen }\end{array}$ \\
\hline B & Konsumen/Pelanggan & Kinerja Dosen \\
\hline C & Proses Bisnis Internal & $\begin{array}{l}\text { Penelitian, Pengabdian kepada Masyarakat, } \\
\text { Publikasi Ilmiah dan Pendidikan }\end{array}$ \\
\hline D & $\begin{array}{l}\text { Belajar } \\
\text { Pertumbuhan }\end{array}$ \\
\hline
\end{tabular}

Sumber: data diolah 


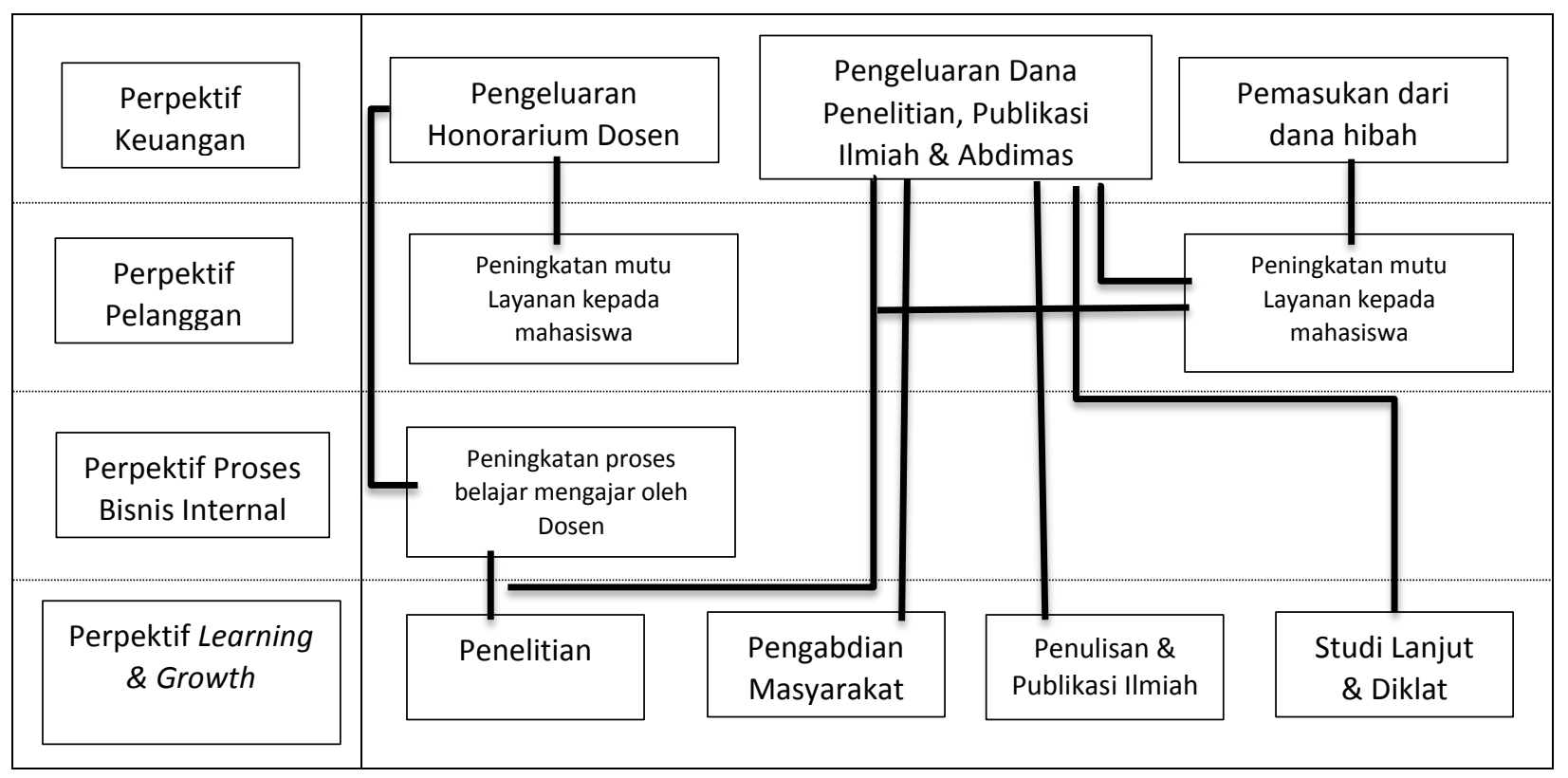

Gambar 2 Hubungan Keterkaitan antar tujuan-tujuan strategik

2. Indikator-Indikator Kinerja Dosen

Penulis memformulasikan indikator-indikator kinerja dosen beserta Key Performance Indicator (KPI) untuk tujuan pengukuran tingkat pertumbuhan perguruan tinggi dan posisi keunggulan bersaing dari STT Sangkakala. Lingkup KPI pada institusi STT Sangkakala diukur meliputi sumber daya manusia, system penggajian, kinerja dosen, kepuasan pelanggan dan learn \& Growth.

Tabel 2 Indikator-Indikator Kinerja Dosen

\begin{tabular}{|l|ll|}
\hline \multicolumn{1}{|c|}{ Tujuan Strategik } & & Key Perfomance Indicator (KPI) \\
\hline Finansial & - & Honor dosen \\
& - & Dana hibah \\
& - & Dana stimulan \\
\hline $\begin{array}{l}\text { Konsumen/pelanggan: } \\
\text { - Kepuasan mahasiswa }\end{array}$ & - & Nilai kepuasana mahasiswa \\
$-\quad$ Kepuasan dosen & - & Nilai kepuasan dosen \\
\hline $\begin{array}{l}\text { Proses bisnis internal: } \\
\text { - Kinerja dosen }\end{array}$ & - & \\
\hline $\begin{array}{l}\text { Learn and Growth: } \\
-\quad \text { Penelitian }\end{array}$ & - & Prosentase kehadiran dosen \\
$-\quad$ Pengabdian masyarakat & - & Prosentase nilai terkumpul \\
$-\quad$ Karya ilmiah & - & Prosentase penelitian dosen \\
$-\quad$ Pendidikan & - & Prosentase publikasi ilmiah \\
\hline
\end{tabular}

Sumber: data diolah

3. Penilaian Kinerja Dosen

Berdasarkan dokumen literatur/pedoman evaluasi dosen institusi diperoleh data-data berupa bobot kinerja dosen seperti pada tabel 3 dibawah ini. 
Tabel 3 Penilaian Kinerja Dosen

\begin{tabular}{|c|c|c|}
\hline $\mathrm{NO}$ & KRITERIA & BOBOT \\
\hline 1 & $\begin{array}{l}\text { Proses belajar mengajar: } \\
\text { a. Evaluasi Kepuasan Mahasiswa } \\
\text { b. Memenuhi jumlah tatap muka sesuai dengan jadwal, termasuk } \\
\text { hadir dan selesai tepat waktu } \\
\text { c. Membuat soal ujian tepat waktu } \\
\text { d. Jawaban dan mengoreksi tepat waktu } \\
\text { e. Menguji magang kerja dan skripsi sesuai dengan penjadwalan } \\
\text { f. Membuat diktat kuliah }\end{array}$ & $\begin{array}{l}10 \% \\
10 \% \\
5 \% \\
3 \% \\
2 \% \\
5 \% \\
\end{array}$ \\
\hline 2 & $\begin{array}{l}\text { Bimbingan dan konsultansi: } \\
\text { a. Memberikan bimbingan magang kerja/KKN \& skripsi } \\
\text { b. Menjadi penasehat akademik (dosen wali) }\end{array}$ & $10 \%$ \\
\hline 3 & $\begin{array}{l}\text { Jenjang Pendidikan \& Jabatan Fungsional: } \\
\text { a. Jabatan Akademik } \\
\text { b. Lama Jabatan Akademik } \\
\text { c. Jenjang Pendidikan }\end{array}$ & $20 \%$ \\
\hline 4 & $\begin{array}{l}\text { Penelitian dan pengabdian masyarakat: } \\
\text { a. Melakukan penelitian } \\
\text { b. Publikasi ilmiah } \\
\text { c. Melakukan pengabdian masyarakat }\end{array}$ & $\begin{array}{l}10 \% \\
10 \% \\
10 \%\end{array}$ \\
\hline 5 & $\begin{array}{l}\text { Tugas lain-lain diluar tugas utama: } \\
\text { a. Bertugas sebagai panitia } \\
\text { b. Mengikuti seminar/pelatihan }\end{array}$ & $\begin{array}{l}2 \% \\
3 \% \\
\end{array}$ \\
\hline
\end{tabular}

Sumber:data diolah

4. Context Diagram

Konteks diagram merupakan gambaran yang seara umum dilakukan oleh institusi dalam melakukan analisis balanced scorecard. Pada gambar 3 dapat dilihat bahwa entity external: intistusi dengan program studi memberikan informasi tentang tujuan institusi terkait dengan kinerja dosen. Entity external lainnya adalah mahasiswa, dosen, SDM (ADAK), keuangan BAK memasukan data yang diperlukan dalam Analisa balanced scorecard sesuai dengan unitnya masing-masing yang nantinya digunakan untuk membuat penilaian kinerja dosen yang nantinya ditungaknan dalam bentuk laporan. 


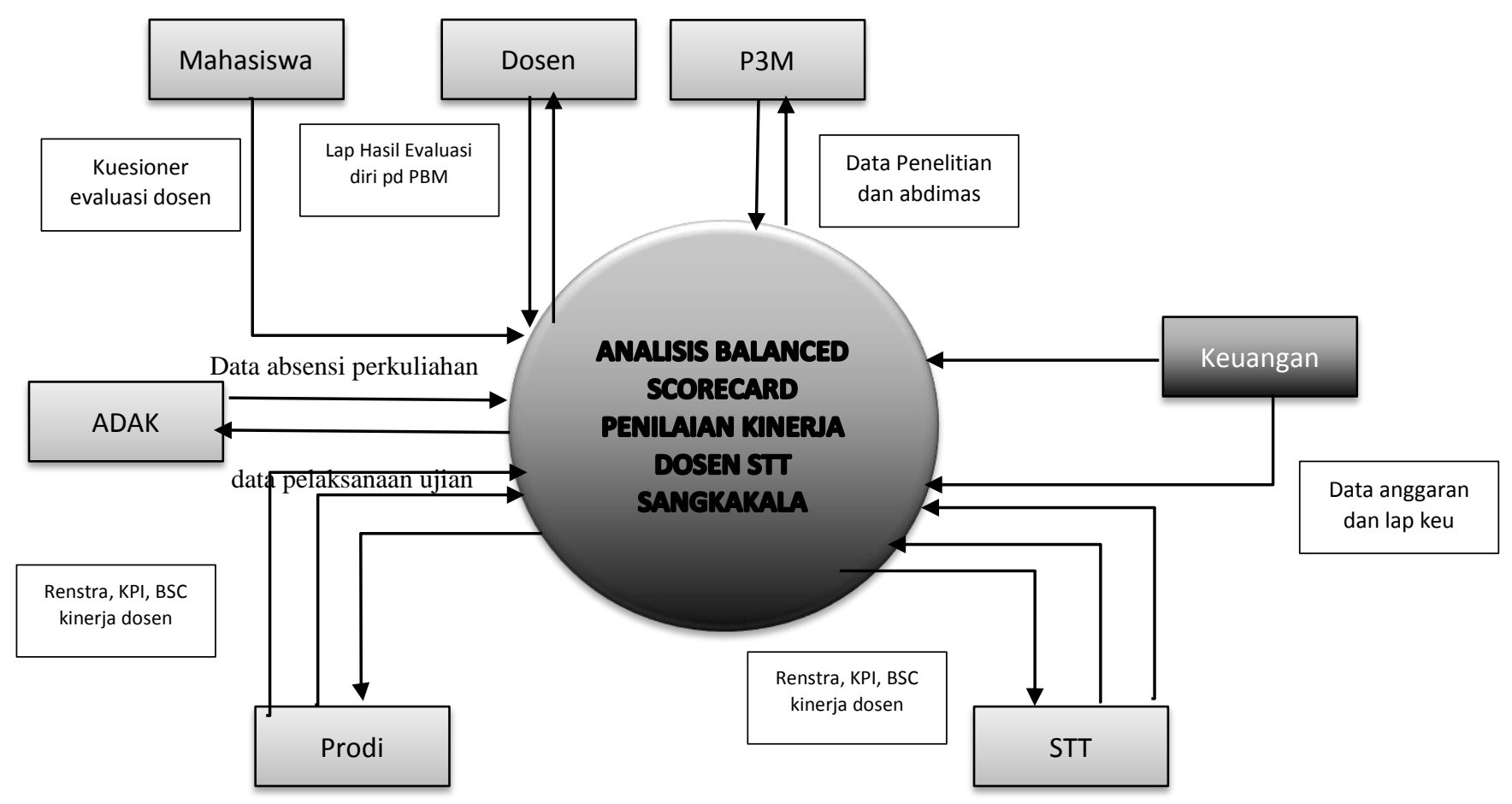

Gambar 3 Context Diagram

Dalam proses penilaian kinerja dosen, peran serta unit pendukung dari institusi dalam memberikan data dan informasi terkait rekam jejak dosen dalam kegiatan tri dharma perguruan tinggi dalam kurun waktu tertentu. Pada context diagram terdapat beberapa entity external yang terlibat dalam proses penilaian kinerja dosen sebagai sumber data dan informasi dalam Analisis balanced scorecard. Pengembangan secara mendalam dari konteks diagram ini ke dalam levwl-level berikutnya akan membentuk subsistem-subsistem dari proses entity external ke proses analisis balanced scorecard seperti tabel berikut:

Tabel 4 Sumber data dan subsistem

\begin{tabular}{|c|c|c|c|}
\hline Tujuan Strategik & Key Performance Indicator & Sumber Data & Sub Sistem \\
\hline Finansial & $\begin{array}{ll}\text { - } & \text { Honorarium Dosen } \\
\text { - } & \text { Dana Hibah } \\
\text { - } & \text { Dana Stimulan }\end{array}$ & Bag. Keuangan & Sub system EKEU \\
\hline $\begin{array}{l}\text { Konsumen/pelanggan: } \\
\text { - } \quad \text { Kepuasan } \\
\text { mahasiswa } \\
\text { - } \quad \text { Kepuasan dosen }\end{array}$ & $\begin{array}{l}\text { - Nilai kepuasan mahasiswa } \\
\text { - Nilai kepuasan dosen }\end{array}$ & $\begin{array}{ll}\text { - } & \text { Kuesioner } \\
\text { mahasiswa } \\
\text { - } & \text { Kuesioner } \\
\text { dosen }\end{array}$ & $\begin{array}{l}\text { Subsistem EDOM } \\
\text { Subsistem EDOS }\end{array}$ \\
\hline $\begin{array}{l}\text { Proses bisnis internal: } \\
-\quad \text { Kinerja dosen }\end{array}$ & Prosentase kehadiran dosen & Data ADAK & Subsistem EADAK \\
\hline
\end{tabular}




\begin{tabular}{|c|c|c|c|}
\hline Tujuan Strategik & Key Performance Indicator & Sumber Data & Sub Sistem \\
\hline & $\begin{array}{ll}\text { - } & \text { Prosentas ketersediaan soal } \\
& \text { ujian } \\
\text { - } & \text { Prosentase nilai terkumpul } \\
\text { - } & \text { Bimbingan dosen }\end{array}$ & $\begin{array}{ll}\text { - } & \text { Data ADAK } \\
\text { - } & \text { Data ADAK } \\
\text { - } & \text { Data prodi }\end{array}$ & $\begin{array}{l}\text { Subsistem } \\
\text { EPRODI }\end{array}$ \\
\hline \begin{tabular}{ll}
\multicolumn{2}{l}{ Learn \& Growth: } \\
- & Penelitian \\
- & Abdimas \\
- & Karya Ilmiah \\
- & Pendidikan
\end{tabular} & $\begin{array}{ll}\text { - } & \text { Prosentase penelitian dosen } \\
\text { - } & \text { Prosentasi abdimas } \\
\text { - } & \text { Prosentase publikasi ilmiah } \\
\text { - } & \text { Prosentase PBM }\end{array}$ & $\begin{array}{ll}\text { - } & \text { Data P3M } \\
\text { - } & \text { Data P3M } \\
\text { - } & \text { Data P3M } \\
\text { - } & \text { Data ADAK }\end{array}$ & $\begin{array}{l}\text { Subsistem EP3M } \\
\text { Subsistem EADAK }\end{array}$ \\
\hline
\end{tabular}

Sumber: data diolah

\section{PENUTUP}

Berdasarkan hasil penelitian dapat disimpulkan bahwa; 1) Penilaian kinerja dosen dengan metode balance scorecard memiliki 3 objek perspektif finansial, yaitu honorarium dosen, dana hibah/ekternal, dana stimulant; 2 strategi objectives perspektif pelanggan, yaitu peningkatan kepuasan mahasiswa, peningkatan kepuasan dosen; 4 strategi objektif perspektif proses bisnis internal, yaitu prosentase kehadiran dosen, prosentasi ketersediaan soal ujian, prosentase nilai terkumpul, bimbingan dosen.; dan 4 strategi objektif perspektif learn \& growth yaitu prosentase penelitian dosen, prosentase pengabdian masyarakat, prosentase publikasi ilmiah, dan prosentasi pendidikan; 2) Penilaian kinerja dosen dari sisi pengembangan perangkat lunak secara terintegrasi berdasarkan sumber data pada setiap unit pendukung pada institusi STT Sangkakala terdapat beberapa subsitem-subsistem yaitu: Subsistem EKEU, subsistem EDOM, subsistem EDOS, subsistem EPRODI, subsistem EP3M, dan subsistem ADAK. Hasil perancangan dan pengukuran ini diperoleh dari berbagai rumusan balanced scorecard STT Sangkakala yang mencakup tujuan, indikator, sasaran dan inisiatif yang terdapat pada context diagram dan key performance.

\section{DAFTAR PUSTAKA}

Djunaidi, Much. and Munawir, Hafidh and Utami, Yogi Umi. 2006. Evaluasi Kualitas Kinerja Proses Belajar Mengajar dengan Metode Focus, Jurnal Ilmiah Teknik Industri, Vol.05 (No.01). pp. 7-16. ISSN 1412-6869

Genoveva \& Elisabeth V. Mutiarawati. 2004. Menyusun Sistem Penilaian Kinerja Dosen yang Mendukung Tri Dharma Perguruan Tinggi. Jurnal Pendidikan dan Kebudayaan, Vol. 10 No.051

Henderi. 2007. Perencanaan Strategis Sistem Informasi Perguruan Tinggi Studi Kasus di STMIK RAHARJA. Jurnal Cyber Raharja ISSN 1412-1344. 4 (2) (2007)

I Wayan Badra, Johana. E. Prawitasari.2003. Kinerja Dosen Hubungan Antara Motivasi dan Stress dengan Kinerja Dosen Tetap Akper Sorong. Jurnal MPK, Volume. 06/Nomor 04/2003. Indrajit, Eko,R; Djokopranoto, R. 2006. Manajemen Perguruan Tinggi Modern. Penerbit Andi: Yogyakarta 
Kenneth C Laudon, Jane P. Laudon.2007. Management Information Systems Managing the Digital Firm Tenth Edition, Pearson Education, Inc., Upper Saddle river, New Jersey

Kusumadewi, Sri.2004. fuzzy quantification theory untuk analisis hubungan antara penilaian kinerja dosen oleh mahasiswa, kehadiran dosen, dan nilai kelulusan mahasiswa, Media Informatika, Vol. 2, No. 1, Juni 2004, 1-10 ISSN: 0854-4743 2004

Kusrini.2006. Perancangan Sistem Pendukung Keputusan untuk Evaluasi Kinerja Dosen di STMIK AMIKOM Yogyakarta. Jurnal Ilmiah DASI Vol 7 No 2 Juni 2006, ISSN:1411-3201)

Rangkuti, Freddy. 2019. SWOT Balanced scorecard, Teknik Menyusun Strategi Korporat yang Efektif plus cara mengelola kinerja dan risiko. Gramedia: Jakarta.

Miles Mathew A. And A. Michael Hubberman. 1984. Qualitatif Data Analysis. Sage Publication Inc.

Moleong, Lexy. 2007. Metode Penelitian Kualitatif. Bandung: Remaja Rosda Karya. 